\title{
Japan's seismic tragedy at Kobe
}

\section{The most destructive Japanese earthquake since that in Tokyo in 1923 will have implications far outside Japan as attention there turns to the search for safety in a seismically hazardous place.}

THE tragic aftermath of last week's earthquake at Kobe, southwest of Tokyo, will cast a long shadow, and not only in Japan. There, in what is arguably the best-ordered society in the world, it will be an affront to everyday contentment that nearly 5,000 people have been killed and 250,000 people made homeless by a mere geological event. Like Manhattan, but on a vastly larger scale, the Pacific seaboard of Japan is a manmade dwelling place built with ingenuity and a breathtaking regard for appearance. It will surprise nobody that the survivors will be in shock for many months to come. Nature hereby sends its sympathy to all those in Japan who may read this and what follows.

It is also no surprise that the Tokyo stock market has taken a tumble in the past few days. The immediate economic disruption of the earthquake is something to be reckoned with, but the money-bags no doubt also calculate that Japan will now embark on a programme of public works intended further to protect its people against seismic danger. Even now-rich Japan will be hard-pressed both to strengthen buildings against the next big earthquake and to continue its investment in the industries that have made it an economic powerhouse in the past four decades. But nobody should underestimate the resourcefulness of those who have built the manmade industrial complex of Japan in such seismically hostile territory.

The lesson of this earthquake, as of all others, is that seismic waves themselves do not kill people in large numbers. But buildings and other components of the built environment do that when they collapse, or when they are set alight by ruptured gas supplies. Last week's destruction shows how huge the destruction can be. But Japan's familiarity with earthquakes and their destructive effects is also illustrated by the general use of the word 'tsunami' for the tidal waves caused by submarine earthquakes, often at great distance. Japan is no stranger to events like that at Kobe last week.

What is to be done? More seismology is not the immediate answer, although there is some evidence that the rescue services would have been more quickly in action if there had been a more rapid seismic assessment of the magnitude of the Kobe earthquake and of its character and location. In Japan, where even the railways run like clockwork, there will be shame that the rescue services seem not to have been as quickly off the mark as expectations of efficiency require. Rescue can save lives and (by firefighting) even property. Japan, with its vulnerability to earthquakes, needs a careful reassessment of what can be done to bring its vast resources of energy and equipment to bear on the next big earthquake, whenever that will be. (No doubt they will also be dusting off the plans for rescue in California after last week's experience.)

Next comes civil engineering. Experience in all seismic regions, but notably in Japan and California, has amply shown what benefits can accrue from buildings designed against earthquakes. The whole world, not just Japan, needs a careful survey of the buildings surviving from last week and an understanding of the mechanical reasons for their survival. That will be the easy part. Devising new construction codes and enforcing them will no doubt follow, with all the horrendous cost implications they must entail. But the retro-construction of existing buildings and motorway routes may prove to be less expensive than starting all over again. Japan may be in for a period in which demolition outpaces new construction.

But are these not poor substitutes for the prize that seismology should deliver to Japan - an effective seismic prediction service? That, sadly, is an impossible dream for the present, and may remain so for many years and even forever. Japan's own publicly funded prediction service has a poor reputation and no record of even meagre success. The search for premonitory signs of earthquakes (such as methane emission as well as seismic signals), conducted with immense if fitful enthusiasm, has so far yielded nothing substantial. And carefully instrumented seismic regions, as are some sections of the San Andreas fault in California, are unlikely in the near future to yield predictions of the kind on which rescue services can take action. Until that is possible, predictions (given unavoidable uncertainty) may do more harm than good.

So is there nothing seismology can do? Luckily, the tale is not entirely gloomy. Eventually, measurements of seismic strain in the neighbourhood of active faults may help to tune construction codes more accurately to regional long-term seismic risks. As things are, neither the data not the understanding exist for such an exercise. Given the huge extra costs of earthquake-proof construction, the case for collecting data and for their intelligent analysis is overwhelming. But seismology must be careful not to over-sell the promise of these long-term studies. At some level, a degree of fatalism is required of governments and the people they represent. Occasional catastrophes are a part of the price of living on the surface of a tectonically active planet. Pity Kobe nevertheless. 